\title{
ПЕРСОНАЛІСТИЧНА БІОЕТИКА У ЗАКОНОДАВЧОМУ РЕГУЛЮВАННІ ДОПОМІЖНИХ РЕПРОДУКТИВНИХ ТЕХНОЛОГІЙ В УКРАЇНІ
}

\author{
ДВНЗ «Тернопільський державний медичний університет ім. І.Я. Горбачевського МОЗ України»
}

\begin{abstract}
Мета: формування знань щодо етичних та законодавчих документів, які захищають індивідуум, суспільство і людство в цілому від небажаних і згубних наслідків упровадження в практику нових медико-біологічних технологій.

Матеріали і методи. За допомогою бібліографічного та герменевтичного методу проведено аналіз нормативних документів та етичних актів.

Результати. Наукові дослідження біологічної природи людського ембріона свідчать про те, що від моменту запліднення ембріон має всі характеристики людської істоти. Це зумовлює необхідність законодавчого регулювання допоміжних репродуктивних технологій та їх альтернативи - НаПроТехнології для вирішення проблем неплідності, ставлення до статусу ембріону людини як до людської особи, наділеної людською гідністю, що від моменту запліднення заслуговує пошани.

Висновки. У сучасній системі охорони здоров'я виникає необхідність перегляду чинного законодавства через усвідомлення основних засад персоналістичної біоетики щодо втручань у людський організм, зокрема щодо вирішення проблем неплідності.
\end{abstract}

КЛЮЧОВІ СЛОВА: допоміжні репродуктивні технології, статус ембріону, НаПроТехнології, неплідність.

За даними Міністерства охорони здоров'я України, на сьогодні близько 1 млн подружніх пар страждають на непліддя. Дослідження виявили, що у 55-65\% випадків неплідною є жінка, а у 4555\% - чоловік [4]. У 75-80\% випадків причиною непліддя у жінок є аборти, використання засобів контрацепції, а у 15-25\% - запальні процеси статевих органів. Лікування непліддя все частіше поєднується 3 пропагандою використання методів допоміжних репродуктивних технологій, зокрема штучного запліднення in vitro з наступним перенесенням ембріона в організм матері і сурогатного материнства [10].

У 1978 р. в Англії народилася Луїза Браун перша у світі дитина із пробірки [4]. Перед тим, як 10 листопада 1977 р. відбулося перенесення 8-клітинного ембріона у порожнину матки, що призвело до настання маткової вагітності, було зроблено близько 600 спроб ембріональних переносів. Щороку у світі внаслідок екстракорпорального запліднення народжується 30 тис. дітей. Проте це лише 3-5\% з усієї кількості ембріонів, які остаточно розвинулися і народилися. Відомим $€$ факт, що у Великобританії 1 серпня 1996 р. внаслідок закінчення п'ятирічного терміну кріоконсервації ембріонів було вбито 3300 людських життів [10].

Штучне запліднення «у пробірці» $є$ заплідненням поза шлюбом: подружнім парам залишається лише генетична спадковість, їх бажання мати дитину і виношування плоду жінкою. А особи, які

(C) Т.І. Толокова, 2015 здійснюють визначальну дію при штучному заплідненні, є сторонніми особами щодо сімейної пари [3].

Мета роботи: формування знань щодо етичних та законодавчих документів, які захищають індивідуум, суспільство і людство в цілому від небажаних і згубних наслідків упровадження в практику нових медико-біологічних технологій, глибокої переконаності в необхідності неухильного дотримання етичних і моральних норм, правил і принципів у діяльності медичних працівників.

Матеріали і методи. За допомогою бібліографічного та герменевтичного методу проведено аналіз нормативних документів та етичних актів.

Результати дослідження та їх обговорення. Допоміжні репродуктивні технології використовуються в Україні з 1987 р. і, згідно з термінологією Всесвітньої організації охорони здоров'я (2004), є лікуванням і процедурами, які включають «in vitro» маніпуляції на людських ооцитах і спермі або ембріонах з метою досягнення вагітності. Це включає, але не обмежує «in vitro» («в пробірці») запліднення і трансцервікальний перенос ембріонів, перенос гамет до фаллопієвих труб, перенос зигот до фаллопієвих труб, перенос ембріонів у порожнину труб, кріоконсервацію гамет і ембріонів, донацію ембріонів і ооцитів і гестаційне сурогатство [6].

Наказом МОЗ України №771 від 23.12.2008 p. було затверджено Інструкцію про порядок застосування допоміжних репродуктивних технологій, відповідно до якої здійснюється донація гамет або ембріона, що є процедурою, за якої 
донори за письмово оформленою добровільною згодою надають свої статеві клітини - гамети (сперму, ооцити) або ембріони для використання іншими особами у «лікуванні безпліддя» [5]. Стаття 290 Цивільного кодексу України передбачає право на донорство, яке включає право повнолітньої дієздатної фізичної особи бути донором репродуктивних клітин [11].

Чи виправдовується благородна мета стати батьками коштом надто великої кількості убитих ембріонів? Чи може жінка, даючи згоду на донорство своїх ооцитів, не усвідомлювати, що тим самим підписує згоду на свідоме убивство генетично їй не чужих людських життів? Сурогатне материнство криє у собі право маніпуляцій стосовно вибору статі, євгенічної селекції ембріонів. Людина, прикриваючись холоднокровним прагматичним прагненням мати за всяку ціну дитину, робить ії продуктом лабораторних технологій.

Стосовно збереження життя людського ембріона при заплідненні у пробірці та при його перенесенні в організм матері на сучасному етапі розвитку технологій постають складні проблеми. Оскільки відсоток вдалої імплантації та успішного розвитку вагітності доволі низький (один-два випадки з десяти), то заради досягнення більшого успіху створюють більше ембріонів - щоб мати можливість повторити спробу в разі попередньої невдачі. Утворюється «надчисло» ембріонів, яке використовується як біоматеріал для експериментів, виробництва косметичних засобів чи трансплантації органів або тканин, що є морально неприпустимо, бо це означає вбивство донора. Ці ембріони втрачають статус «суб'єктів» і стають «об'єктами», продуктами селекції тощо [11]. Ембріон має мету, цінність в собі і не повинен бути зведений до рівня предмету, засобу вжитку, не повинен бути позбавлений своєї ідентичності та людських прав. Тому експерименти мають проводитися лише з лікувальною метою, слугувати ембріону, а не нищити невинне людське життя. Свідоме знищення ембріонів, як і штучний аборт, з погляду персоналістичної біоетики є навмисним вбивством людських істот.

За статистикою з 95\% запліднених in vitro приречених на смерть ембріонів частина $з$ них знищується свідомо - через непридатність для перенесення в матку чи труби; інші спочатку зберігаються як «запасні» для подальших спроб запліднення цієї самої жінки (генетичної матері) чи інших жінок, або із закінченням терміну зберігання вони знищуються, тому що пізніше не гарантується якість їхньої консервації, чи застосовуються в експериментальних дослідженнях [1].

Людський ембріон є людською особою від моменту запліднення. Відомий німецький ембріолог Е. Блехшмідт ще наприкінці XX ст. у запропонованій ним теорії розвитку індивідуальності дійшов висновку, що людиною не можна стати, нею можна лише бути від першої миті свого існування [2]. Сьогодні з розшифруванням генома людини не залишилось сумнівів, що від моменту запліднення бере початок життя людської особи. Визнання за ембріоном статусу людини $€$ питанням про саморозуміння людини, про відповідальність перед тим, хто з'являється на світ, про людські права на рівноправність і на недискримінацію, які визнані на міжнародному рівні для всіх людських індивідів [10].

Наукові дослідження біологічної природи людського ембріона свідчать про те, що від моменту запліднення ембріон має всі характеристики людської істоти:

- нову і тільки їй властиву сутність, цілком відмінну від інших істот, яка має свою власну проект-програму життя і розвитку;

- внутрішній динамізм, що визначається та керується геномом аж до формування дорослої людини; існує у вигляді цілісного організму, тобто біологічної та функціональної єдності, яка має координовану структуру росту та розмноження;

- $€$ автономним, тобто не потребує зовнішнього втручання для підтримання власної життєвої структури;

- здійснює самоконтроль над реалізацією своєї генетичної програми;

- його хромосоми доводять приналежність ембріона до людського роду, яка визначається також через особливості його власної генетичної структури (генома) [9].

Ембріону людини притаманна гідність, бо те, ким стане людина, вже закладене у ньому, але не є ще вираженим і потребує часу для розвитку та остаточного формування, яке не закінчується з народженням. Генетичний розвиток людини не включає в себе зміну ії природи, а лише поступовий прояв тих можливостей та здібностей, якими вона вже володіє від самого початку. Отже, людська особа починає існувати від моменту запліднення.

Сучасна філософська антропологія сформулювала поняття «тілесної особи»: не може існувати людська особа, яка б не була одночасно «я»-тілесним і «я»-духовним [9]. Ця нерозривність духу, душі і тіла свідчить, що «початок тілесної сфери людини означає початок цілої людської особи» [9]. Отже, є біологічні й філософські аргументи того, що ембріон від самого моменту запліднення $є$ людською особою, наділеною людською гідністю, і заслуговує пошани. Це є фундаментом етичного мислення і дій, сенсом етики і моралі. Якщо людина заслуговує на визнання, то вона також заслуговує і на охорону їі життя від моменту запліднення до природної смерті, бо неможливо визнати людину без пошани їі життя. Ембріон теж має особливий мо- 
ральний статус: на будь-якій стадії свого розвитку він є людською особою і носієм людської гідності. Саме тому всі дії щодо ембріона підлягають моральній оцінці, а він сам є суб'єктом фундаментальних моральних прав.

Дух, душа і тіло є нероздільними й необхідними для життя людини на землі від моменту запліднення до природної смерті.

Архієпископ Лука (В.Ф. Войно-Ясенецький) відзначає, що «дух вже в ембріональному стані тіла формує його. Всім клітинам тіла людини притаманна духовна енергія, оскільки вони є живими, а життя від Духа» (пор. Ів. 6, 63).

Визначення, від якого моменту плід вважається особою, повноправною людиною, є підставою моральної оцінки дій, які стосуються ще ненародженої людської істоти. Не можна вважати критеріями буття людської особи появу чи існування у процесі біогенезу людини певної якості, функції чи здатності: народження, здатність до самостійного життя, неврологічний критерій, імплантація чи генетичний критерій. Будь-які спроби визначити «початок» людського життя між заплідненням і народженням безуспішні, бо життя є динамічним процесом. Немає правильнішої відповіді на питання про початок особистого життя людини, ніж та, що воно починається від моменту запліднення.

Сурогатне материнство, зокрема комерційне, в Україні узаконене.

Сурогатні матері - це жінки, які з комерційною метою виношують дітей для подружжязамовників, запліднених у пробірці з їхніх яйцеклітин і сперматозоїдів. Сурогатне материнство стало своєрідним бізнес-проектом. Сурогатні матері віддають своє тіло «в оренду» і розпоряджаються народженими ними дітьми як товаром. При цьому нівелюється цінність Божого дару материнства, а дитина стає об'єктом, річчю, яку можна замовити чи купити. Це суперечить гідності і цінності дитини, як людської особи з моменту запліднення. В енцикліці «Donum vitae» («Дар життя») сказано: «Народження нової особи, де чоловік і жінка співпрацюють з силою Творця, повинно бути плодом і знаком взаємного дарування супругів, їхньої любові та вірності. Вірність супругів включає в себе взаємну повагу їхнього права стати батьком і матір'ю через них самих. Дитина має право бути зачатою, виношеною у лоні матері, приведеною на світ, вихованою у подружжі, знати свою власну ідентичність і досягти свого власного людського розвитку» [12].

Філософська антропологія XX ст. (Макс Шелер) стверджує, що людина існує у трьох вимірах: духовному, душевному і тілесному. Тіло людини не є чимось відокремленим від їі «я», воно є одним із вимірів цілісності особи, і є умовою життя у світі. Папа Іван Павло ІІ вживає терміни «одухотворене тіло» і «втілений дух» [13].

Інструкція «Donum vitae» стверджує, що сурогатне материнство «суперечить єдності подружжя і гідності людського дітонародження. Сурогатне материнство - це реальна неспроможність виконувати обов'язки материнської любові, подружньої вірності і відповідального материнства. Воно порушує гідність і право дитини бути зачатою, виношеною в лоні своєї матері, приведенню на світ і вихованою своїми батьками. Воно завдає духовної, психічної, фізичної і моральної шкоди сім'ям» [12].

Не існує права мати дитину. Одруження не наділяє подружжя правом мати дитину. Дитина має право на сім'ю, виховуватись 3 гідністю людської особи. Неплідні пари мають нагоду до іншого важливого служіння у справі життя людської особи, як, наприклад, усиновлення покинутих дітей [14].

У Німеччині сурогатне материнство заборонене на законодавчому рівні. В Італії намагання рекламувати комерціалізацію гамет, ембріонів чи організувати сурогатне материнство, карається терміном від трьох місяців до двох років позбавлення волі, окрім цього штрафом від 600 тис. євро до 1 млн євро. Однак в Італії існують певні веб-сайти італійською мовою, де пропонують послуги сурогатних матерів з України, і де замовники за каталогом можуть обрати українську жінку, яка виносить їхню дитину.

Альтернативою узаконення сурогатного материнства в Україні є турбота про усиновлення дітей-сиріт, що є не тільки благородною справою, але й обов'язком суспільства і держави [14].

Альтернативою репродуктивних технологій є НаПроТехнології, тобто методи, які опираються на підтримку і корекцію природних процесів в організмі чоловіка і жінки, спрямованих на зачаття і виношування дитини. Цей новий напрям у репродуктивній технології був започаткований у 90-х роках XX ст. Томасом Гілджерсом (США), професором Крейгтонського університету, директором Інституту із вивчення репродукції людини імені Папи Павла VI, який один з небагатьох лікарів і вчених у світі розпочав у 1970-х роках наукове дослідження природного циклу жінки. В основі лікування жіночого безпліддя лежить модель Крейгтона - популярний у США метод спостереження за циклом жіночої плідності, що дозволяє об'єктивно оцінити гормональні зміни протягом циклу. Клініки НаПроТехнологій також Функціонують в Ірландії, Англії, Франції, Німеччині, Словаччині, Польщі.

Незважаючи на новизну НаПроТехнологій, їх застосування є досить ефективним і безпечним. Journal of the American Board of Family 
Medicine («Журнал Американського Управління Сімейною Медициною») у жовтні 2008 р. опублікував результати досліджень, здійснених у 2008 р. вченими Міжнародного Інституту реконструктивної репродуктивної медицини. Дослідження показало, що із 1100 подружніх пар, які зіткнулися із проблемою безпліддя, 52,8\% змогли народити живу дитину за допомогою НаПроТехологій. При цьому третина учасників дослідження раніше безуспішно зверталися до штучного запліднення. Серед респондентів, які раніше не зверталися до запліднення «в пробірці», показник народжуваності був вищим і становив 61,5\%. У переважній більшості жінок вагітність була одноплідною, на відміну від тих, котрі були отримані за допомогою запліднення «в пробірці», де частота багатоплідних вагітностей становила близько 20\%. Складністю, котра властива новітнім репродуктивним технологіям, є часті викидні. Їх кількість становить близько 40\%. При застосуванні НаПроТехнологій ризик передчасних пологів, народження дитини з дуже низькою масою тіла та сер- йозними ускладненнями вагітності є мінімальним. НаПроТехнології є ефективними для жінок зрілого дітородного віку (після 40 років), тоді як шанси завагітніти за допомогою штучного запліднення після 35 років суттєво знижуються.

\section{Висновки}

На сучасному рівні дослідження біоетичних проблем щодо регулювання допоміжних репродуктивних технологій в Україні створюються умови та виникає необхідність перегляду чинних законодавчих актів через усвідомлення основних засад персоналістичної біоетики щодо втручань у людський організм, зокрема щодо вирішення проблем неплідності.

Перспективи подальших досліджень полягають у належному інформаційному забезпеченні в Україні та вивченні ефективності впровадження НаПроТехнологій, як етичного способу подолання проблеми неплідності, враховуючи також високу ефективність цих методів та меншу собівартість порівняно з допоміжними репродуктивними технологіями.

\section{Список літератури}

1. Біоетика : підр. / Згречча Е., Спаньйоло А. Дж., П'єтро М. Л. ді [та ін.]; пер. з італ. В. Й. Шовкун. - Л. : Видавництво ЛОБФ «Медицина і право», 2007.

2. Блехшмідт Е. Збереження індивідуальності. Людина - особа від самого початку. Дані ембріології людини / Е. Блехшмідт. - Л., 2003. - 120 с.

3. Костін І. Деякі питання правового регулювання репродуктивного запліднення / І. Костін, О. Бондар // Укр. мед. часоп. - 2009. - № 3. - С. 52-53.

4. Овчинникова М. Б. Техника жизни, которая ведет к смерти / М. Б. Овчинникова. - М. : Фавор, 2002. - 352 с.

5. Про затвердження Інструкції про порядок застосування допоміжних репродуктивних технологій №771 від 23.12.2008 р. : наказ МОЗ України [Електронний документ]. - Режим доступу : http://www.moz.gov.ua. - Haзва з екрану.

6. Про затвердження умов і порядку застосування штучного запліднення та імплантації ембріона (ембріонів) і методів їх проведення : наказ МОЗ України №24 від 04.02.1997 р. [Електронний документ]. - Режим доступу : http://www.moz.gov.ua. - Назва з екрану.

7. Силуянова И. Этика врачевания / И. Силуянова. - М. : Изд-во Моск. Подворье Свято-Троицкой Сергиевой Лавры, 2001. - 319 с.

8. Сімейний кодекс України від 10.01.2002 р. (№ 2947) // ВВР №21-22.

9. Судо Ж. Семья и биоэтика. Материалы международного симпозиума / Ж. Судо. - СПб : Март, $1998 .-$ C. $115-145$.

10. Терешкевич Г. Т. Біоетика в системі охорони здоров'я і медичної освіти: навч. посібн. / Г. Т. Терешкевич. Л. : Світ, 2008. - 344 с.

11. Цивільний кодекс України від 16.10.2003 р. (№ 435-IV) // BВP. - № 40 - 43/203.

12. Congregazione per Dottrina della Fede. Istruzione Donum Vitae (22 febbraio 1987). - Citta del Vaticano, 1987. - 168 p.

13. Giovanni Paolo II. Lettera Enciclica Evangelium Vitae (25 marzo 1995). - Citta del Vaticano, 1995. - 190 p.

14. Grange D. L'enfant derriere la vitre / D. Grange. - Paris : Encre, 1987. - 288 p.

\section{ПЕРСОНАЛИСТИЧЕСКАЯ БИОЭТИКА В ЗАКОНОДАТЕЛЬНОМ РЕГУЛИРОВАНИИ ВСПОМОГАТЕЛЬНЫХ РЕПРОДУКТИВНЫХ ТЕХНОЛОГИЙ В УКРАИНЕ}

Т.И. Толокова

ДВНЗ «Тернопольский государственный медицинский университет им. И.Я. Горбачевского МОЗ Украины»

Цель: формирование знаний о нравственных и законодательных документах, которые защищают индивидуум, общество и человечество в целом от нежелательных и пагубных последствий внедрения в практику новых медико-биологических технологий.

Материалы и методы. С помощью библиографического и герменевтического метода проведен анализ нормативных документов и этических актов. 
Результаты. Научные исследования биологической природы человеческого эмбриона свидетельствуют о том, что с момента оплодотворения эмбрион имеет все характеристики человеческого существа. Это обуславливает необходимость законодательно урегулирования вспомогательных репродуктивных технологий и их альтернативы - НаПроТехнологии для решения проблем бесплодия, отношения к статусу эмбриона человека как человеческой личности, наделенной человеческим достоинством, с момента оплодотворения заслуживающей уважения.

Выводы. В современной системе здравоохранения возникает необходимость пересмотра действующего законодательства через осознание основных принципов персоналистической биоэтики касательно вмешательств в человеческий организм, в частности относитьно решения проблем бесплодия.

КЛЮЧЕВЫЕ СЛОВА: вспомагальные репродуктивные технологии, статус эмбриона, НаПроТехнологии, бесплодие.

\section{PERSONALITY BIOETHICS IN LEGISLATIVE REGULATION OF ASSISTED REPRODUCTIVE TECHNOLOGIES IN UKRAINE}

\section{T.I. Tolokova}

SHEI "Ternopil State Medical University named after I.J. Gorbachevskyi Ministry of Health of Ukraine"

Purpose: the formation of knowledge on the ethical and legal documents that protect the individual, society and humanity as a whole from unwanted and harmful effects of implementation in practice of new biomedical technologies.

Materials and methods. By means of bibliographic and hermeneutical methods analysis of standard documents and ethical acts is carried out.

Results. Scientific researches of the biological nature of human embryo testify that from the moment of fertilisation the embryo has all characteristics of human being. It predetermines necessity of legislative regulation of auxiliary reproductive technologies and their alternative - NaProTehnologiyi for the decision of infertility problems, the relation to the status of an embryo of the person as to the human person allocated with human advantage, which from the moment of fertilisation is reputable.

Conclusions. In the modern health care system there is need to review existing legislation through the understanding of the basic principles of personalistic bioethics on interferences in the human body, in particular for solving problems of infertility.

KEY WORDS: assisted reproductive technologies, the status of the embryo, NaProTechnologies, infertility.

Рукопис надійшов до редакції 18.03.2015 р.

Відомості про автора:

Толокова Тетяна Іванівна - к.мед.н., доц. кафедри медичної біоетики та деонтології ДВНЗ «Тернопільський державний медичний університет імені І. Я. Горбачевського МОЗ України», тел (0-352)52-72-33 